\title{
Cycle of changing abundances in the fishes of the Narragansett Bay area*
}

\author{
H. Perry Jeffries \& Mark Terceiro
}

Graduate School of Oceanography, University of Rhode Island, Kingston, Rhode Island 02881, USA

\begin{abstract}
Winter flounder Pseudopleuronectes americanus in Narragansett Bay, Rhode Island, reached peak abundance in 1968 and then went into an 8 yr decline, dropping to $1 / 7$ of its former population size, as estimated from weekly tows by otter trawl. Meanwhile a succession of species increased offshore: red hake Urophycis chuss became the commercial dominant in 1973, the ocean pout Macrozoarces americanus and silver hake Merluccius bilinearis in 1974, but among these coastal migrants only scup Stenotomus chrysops entered the bay in substantial numbers. By 1976 scup had increased 25 times in the bay, numerically overshadowing the flounder's 8 yr decline. A year later, flounder began to recover; and after 3 yr (1979) it had achieved its former abundance, only to decrease $58 \%$ over the next 3 yr (1982). Throughout the entire sampling period, migrants and residents bore close inverse relations in bay and sound. Thus, when the bay's flounder population dropped to $1 / 3$ of $i$ its 1968 maximum, migrants dominated the sound's fishes, possibly having been attracted to the immediate area by foods not utilized by the dwindling flounder population during its spring-fall migration from estuarine to coastal waters. These patterns appeared to be initiated by warming and cooling trends so subtle that the effect may have been mediated by predation on larvae at metamorphosis, a process eventually influencing the entire complex of benthic fishes in the Narragansett Bay area.
\end{abstract}

\section{INTRODUCTION}

Fishes of the Narragansett Bay area experienced pronounced changes in abundance during a $17 \mathrm{yr}$ sampling period. Annually, the pattern involved local species mixing with southern migrants during summer-fall and northern migrants during winter-spring. Some visitors entered the bay, while most remained offshore. Several large invertebrates also migrated into the bay during spring and summer. The whole was a complex of ever-changing, seasonally controlled cycles superimposed on longer-term periods of abundance related to minor cycles in climatic temperature.

Winter flounder, the chief year-round resident, peaked in 1968, crashed and then recovered 11 yr later. Catch declined with respect to higher temperatures during 2 periods: (1) the April metamorphosis period; (2) the ensuing 29 mo growth period (Jeffries \& Johnson 1974). In a bivariate linear model incorporating temperature at metamorphosis as 1 factor and temperature during the growth period to catchable size as the

\footnotetext{
- This investigation was supported by the State of Rhode Island; for $2 \mathrm{yr}$, partial support was received from the Office of Sea Grant Programs
}

second factor, increasing temperatures accounted for $92 \%$ of the variation in catch from 1966 through 1973 (Jeffries \& Johnson 1976). This population decrease with increasing temperature, especially during the reproduction period, seemed reasonable, since Rhode Island is zoogeographically well south in the winter flounder's range of abundance. However, actual climatic warming over the 8 yr decline would seem to fall within reproductive tolerances, suggesting that biotic factors were also involved.

The winter flounder's life cycle is unique among demersal fishes. The population migrates inshore during fall, when most other species are leaving for deeper, more benign habitats. Then at the worst of winter, when temperatures are just above freezing (as low as $-1.8^{\circ} \mathrm{C}$, MacPhee 1978) and salinity fluctuates widely, winter flounder start spawning, reaching peak reproductive activity during spring in the Narragansett Bay area, after which they migrate offshore, counter to the mass of migrants coming in to feed in the nutritionally-rich, estuarine habitat. Numerical success must be tied to this escape in time from competitors or predators, a feat that the winter flounder has achieved by virtue of being able to spawn at low temperature in estuarine waters. It follows that climatic variation du- 
ring winter and early spring must be a critical factor, imposed not directly as a physiological limit on reproduction, but possibly by predation during metamorphosis. At this critical stage in the life cycle, the left eye of the planktonic larva moves to the right side, dense pigmentation develops, and the juvenile flounder, now flattened but extremely vulnerable, drops to the bottom.

In this paper, we show that change within the entire complex of demersal fishes begins with a climaticallyinduced effect on the flounder. Biotic effects then become widespread, apparently being mediated through the trophic system.

\section{METHODS}

Weekly, $30 \mathrm{~min}$ otter trawl samples were taken in central Narragansett Bay $\left(41^{\circ} 25^{\prime} N, 71^{\circ} 24^{\prime} \mathrm{W}\right)$ and in Rhode Island Sound $\left(41^{\circ} 25^{\prime} \mathrm{N}, 71^{\circ} 25^{\prime} 30^{\prime} \mathrm{W}\right)$. The trawl measured $10 \mathrm{~m}$ at the mouth and tapered to $1 \mathrm{~m}$ at the throat. Stretched mesh size was $7.6 \mathrm{~cm}$ in the forward half and $5.1 \mathrm{~cm}$ behind the throat. Abundances were expressed as annual totals of mean catch per month. Since sampling was carefully standardized and many samples made up an estimate of annual abundance, we believed that the numbers reported were as precise as could be obtained by traditional methods.

Surface water temperature was measured by bucket thermometer. Each monthly mean, therefore, was subject to daily variation, so for the April period, comparison also included daily air temperature recorded at the Providence Weather Service station in Hillsgrove, Rhode Island. Close correlations between air temperature and surface and bottom water temperatures were given in earlier papers (Jeffries \& Johnson 1974, 1976).

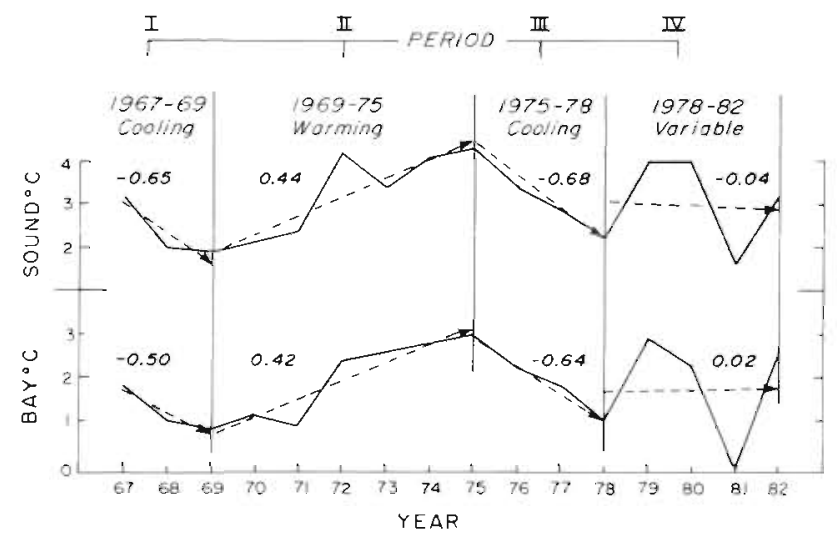

Fig. 1. 1967-82 mean winter surface water temperatures, annually in Rhode Island Sound and Narragansett Bay. Three short-term cooling and warming periods and a variable period are shown. Broken lines indicate least squares fit for each period; slopes of regression $\left(\mathrm{C}^{\circ} \mathrm{yr}^{-1}\right)$ are also indicated

\section{RESULTS}

\section{Winter-spring climate}

Winter temperatures revealed 4 periods of change over $16 \mathrm{yr}$ (Fig. 1). First, water became cooled (1967-68), then warmer (1969-75), cooled again (1975-78), and finally temperatures were variable (1978-82).

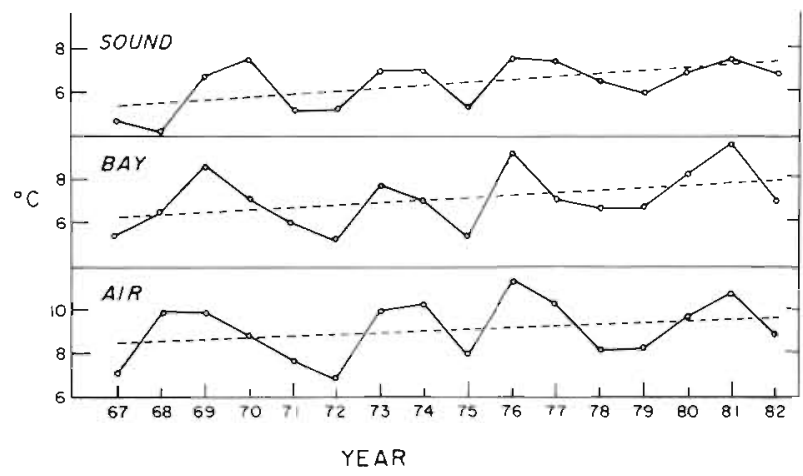

Fig. 2. 1967-82 mean April surface water temperature in Rhode Island Sound and Narragansett Bay; mean April (daily) air temperature near bay station (U.S. Weather Bureau)

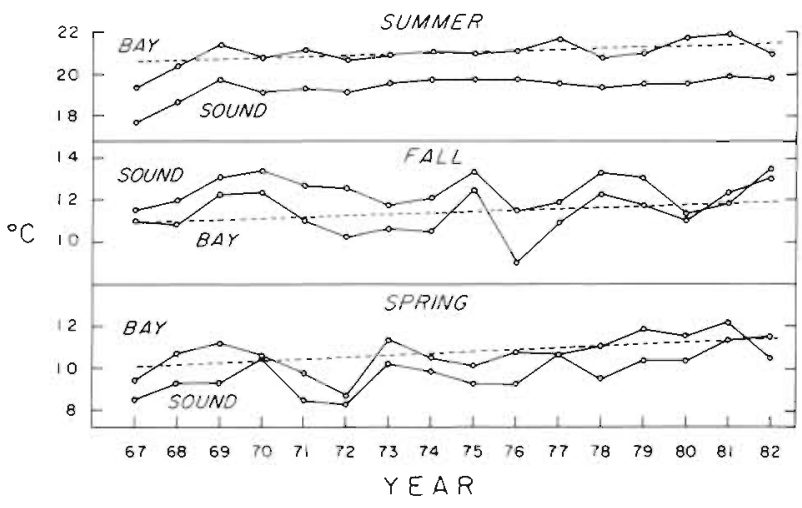

Fig. 3. 1967-82 mean seasonal surface water temperatures, annually in Rhode Island Sound and Narragansett Bay; broken lines indicate least squares fit

Mean April water temperatures ran parallel to air temperature (Fig. 2) recorded at Hillsgrove (U.S. Dept. of Commerce 1966-82). For temperature in the bay:

Water ${ }^{\circ} \mathrm{C}=0.13+0.79\left(\right.$ air $\left.^{\circ} \mathrm{C}\right), \mathrm{r}^{2}=0.74 ; \mathrm{n}=16$. Spring, fall and summer apparently warmed over the entire study $\left(0.07\right.$ to $\left.0.12 \mathrm{C}^{\circ} \mathrm{yr}^{-1}\right)$. Superimposed on each season's trend and the April pattern were cyclic variations from 3 to $5 \mathrm{yr}$ in duration (Fig. 3). The April periods were $1967-72,1972-75,1975-79$. Summer, fall and spring each had the first departure (1967-72), fall and spring produced the second (1972-76) and fall the third (1976-80). Consecutive springs during the late series (1976-82) were generally warmer. 
Fig. 4. 1966-82 mean annual distributions of main demersal species in Narragansett Bay and Rhode Island Sound. Annual totals of mean monthly catches, 30 min tows; note change of scale on abundance $(\mathrm{Y})$ axis

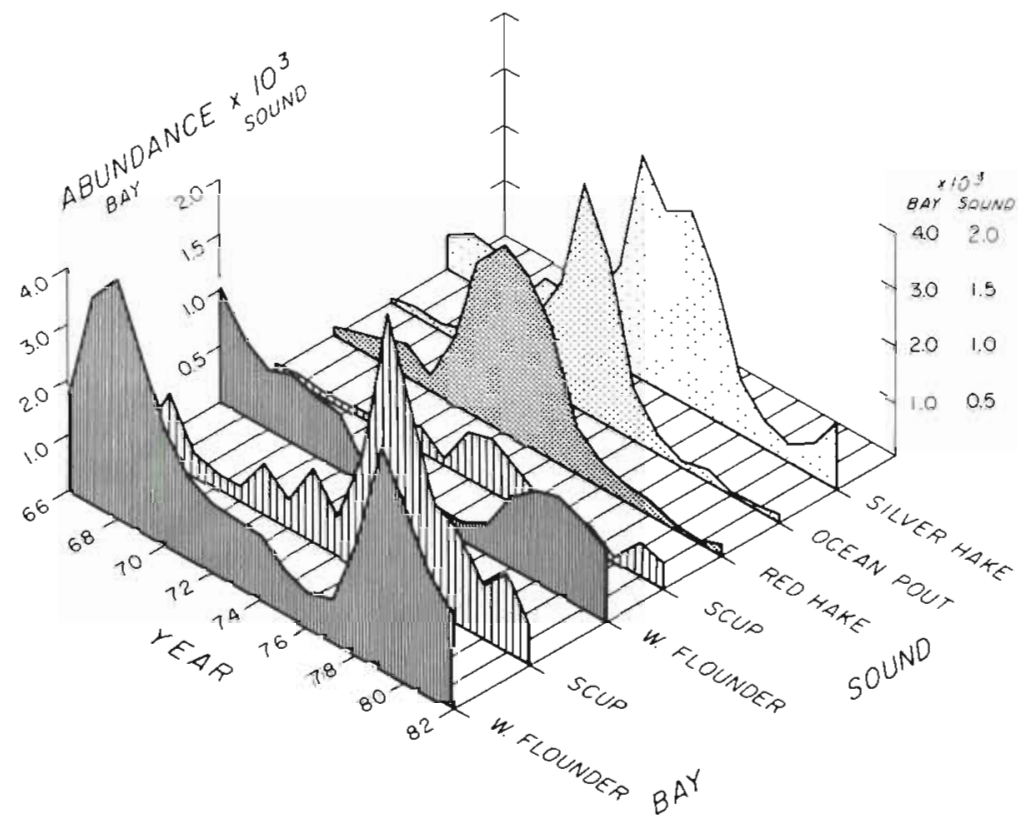

In 1972 all seasons except winter terminated a short period of rise and fall; in 1975-76, fall, spring and April ended the second; a third period displayed by April and fall ended in 1979-80. These 3 to $5 \mathrm{yr}$ departures from apparent trend were significantly shorter than winter's single main period (Periods II and III, Fig. 1), which lasted 9 yr.

\section{Major species}

Winter flounder and scup generally comprised $>80 \%$ of the bay catch, whereas in the sound, red hake, ocean pout and silver hake were well represented (Fig. 4). In the bay, the main pattern was decreasing flounder abundance, droping $86 \%$ from 1968 (4351) to 1976 (613), then recovering rapidly (1978) and peaking again in 1979 (4038), only to decline at a rate similar to that following the 1968 peak. Between the 2 flounder peaks, scup rose 25 -fold, from 208 in 1970 to 4896 in 1976, then decreased $86 \%$ to 700 in 1982 .

In the sound, winter flounder abundances also declined and recovered (Fig. 4), ruling out thermal effects on migration as the sole explanation for the cycle. Rather, recruitment and survival apparently varied progressively over the period of investigation.

In the sound, 3 migrants filled the void caused by the flounder's decline: first red hake, then ocean pout and silver hake. Red hake increased 12-fold over $3 \mathrm{yr}$, ocean pout 55-fold over 8 yr, silver hake 5 -fold over 5 yr.

Superimposed on total catches shown in Fig. 5 are winter's 4 thermal periods (I to IV, from Fig. 1). During Period I, total catch increased amidst progressively colder winters and then fell with the flounder's decline with warmer waters in Period II, but toward the end the total recovered as scup arrived in record strength. Scup abundances carried over into Period III, a cooling phase that presumably set the stage for recovery of winter flounder in Period IV.

In the sound, the major single peak in 1974 was due to seasonal arrivals of ocean pout and the 2 hakes in record abundances. Most of the scup population migrating from the South and outer continental shelf during the mid-70's must have continued into the bay,

The relation between flounder and migrant abundances can be represented by a negative power curve. When flounder abundance dropped below 1500 in the bay, migrants numerically dominated the sound's

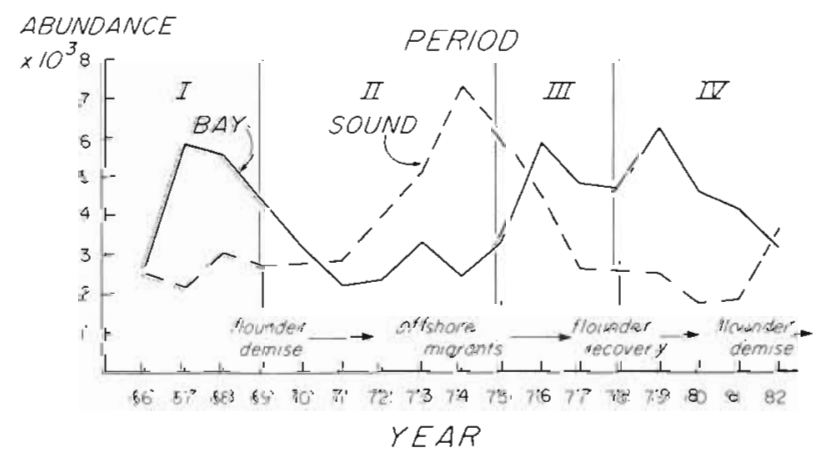

Fig. 5. 1966-82 distributions of total fishes in Narragansett Bay and Rhode Island Sound; annual totals of mean monthly catches, 30 min tows. Winter's 4 thermal periods are superimposed 


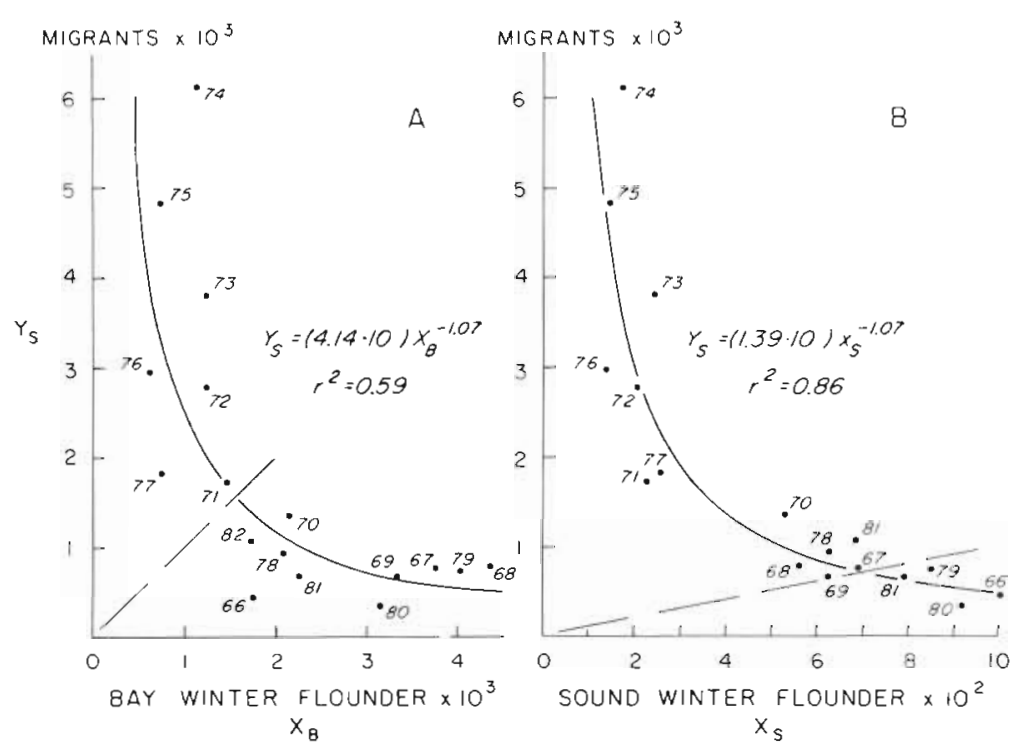

Fig. 6. Power curves for total annual abundances of flounder in relation to total $\mathrm{mi}$ grants (scup, red hake, ocean pout and silver hake) in Rhode Island Sound, 1966-82. (A) Bay winter flounder in relation to sound migrants. (B) Sound winter flounder in relation to sound migrants. Broken line indicates equal apportionment ( $\mathrm{Y} / \mathrm{X}=1)$ fishes (1971-77, Fig. 6A); in the sound itself, dominance changed at 700 flounder (Fig. 6 B). Thus when flounder were abundant in the bay, comparatively few migrants entered the sound.

A multivariate correlation analysis (Dixon \& Brown 1977) was made with bay and sound winter flounder populations as the predictor variables (resident group); the predicted variables were sound scup, bay scup, silver hake, ocean pout, butterfish Peprilus triacanthus and squid Loligo pealei. Both hake species and ocean pout were negatively correlated with bay and sound flounder abundance, while the relation within the flounder population, bay and sound, was positive (Fig. 7). The multiple correlation of each of these 3 species with the winter flounder population were highly significant $(\mathrm{p}<.006)$. Physically coupled habitats were apparently supporting populations coupled in time.

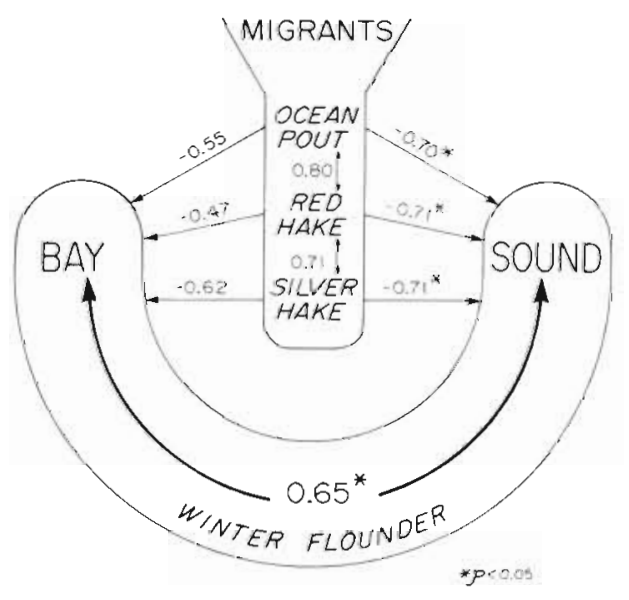

Fig. 7. Multivariate abundance correlations among the resident winter flounder population in bay and sound with seasonal migrants in the sound

\section{DISCUSSION}

Winter flounder abundances were statistically associated with annual variations in winter temperature. Physiologically, however, the range (Fig. 1) would seem to be within reproductive tolerances, suggesting that the negative effect of temperature on abundance was amplified by predatory-prey relations in closely coordinated ways. For example, developmental time to metamorphosis decreases up to $39 \%$ with a $3 \mathrm{C}^{\circ}$ increase (from 5 to $8 \mathrm{C}^{\circ}$, Laurence 1975), which would result in young flounder reaching the bottom noticeably earlier each year, and possibly favoring winter predators such as sculpins (Myxocephalus octodecemspinosus, $M$. aenaeus).

Following its great decline through the mid 1970's, winter flounder began to recover in 1977, which was 2 yr into winter's cooling trend (Phase III, Fig. 1), or 1 yr following the maximum April temperature for the investigation. This lag was reasonable given the approximately $2 \frac{1 / 2}{1}$ y required for flounder larvae to grow to catchable size.

Although somewhat lower each year, winter temperatures during early recovery were still comparable to those occurring in the population's low period. Recovery, then, was based not so much on the actual temperature as it was on the direction of seasonal temperature change. Recovery was faster than decline, taking only 3 yr after the 8 yr decline. Recovery depends on years to catchable size; decline depends on oldest age significantly contributing to catch, which is a basis for the abundance index.

The sound's recovery lagged the bay's by 1 yr, which probably reflected the fact that many small flounder, just large enough to be caught, remained year-round in Narragansett Bay. It was not until the following year 
that they were large enough to migrate from their recruitment area and contribute to the offshore catch.

Temperature's direct effect on scup, the major migrant entering the bay, was clear during the 1972-77 migrant surge, during which summer temperature increased $1.0 \mathrm{C}^{\circ}$ (from 20.7 to $21.7^{\circ} \mathrm{C}$ ) and fall temperature increased $2.3 \mathrm{C}^{\circ}\left(10.2\right.$ to $12.5^{\circ} \mathrm{C}$, Fig. 3). For a scup population wintering off the New Jersey-Carolina coast, and in coastal waters off Southern New England (Bigelow \& Schroeder 1953), this warming was probably sufficient inducement to enter the sound in progressively increasing numbers.

Biological factors may have come into play once the process of change had been initiated by temperature. Scup and winter flounder have similar diets (from the commentary and data given by Bigelow \& Schroeder 1953 and Maurer \& Bowman 1975). Thus the abundance of scup in the bay during the flounder's low period may have been due to an abundance of food.

Equal opportunity occurs when there is no benefit to a species able to migrate between 2 unequally sized habitats (MacArthur 1972), a model that applies to estuarine-coastal fish populations (Jeffries \& Johnson 1974). Scup would not have entered the bay strongly after 1976 because they had less to gain nutritionally, the resident flounder population having now recovered. The interplay of these 2 populations served to maintain consistency of the whole. Total bay fishes in

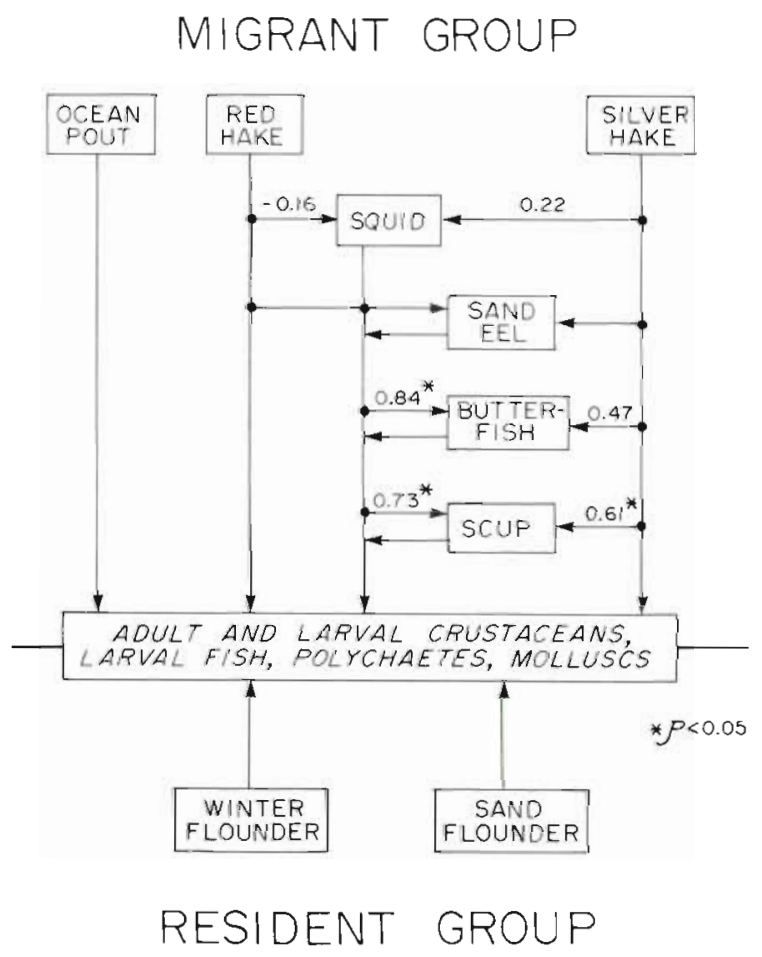

Fig. 8. Proposed trophic scheme showing interacting basis of dependency upon a common resource; partial multivariate correlation coefficients indicated where available
1976, when flounder were at their lowest, was almost the same (5994) as during the peak flounder year (5759 in 1968), a clear example of equal opportunity occurring in a bay-sound system.

The first migrant increasing in the sound was red hake, peaking in 1973. It relied more on crustaceans and less on polychaetes than did winter flounder and scup, but all 3 populations overlapped significantly in resource utilization. So did the ocean pout, also increasing sharply and peaking a year after red hake, apparently having switched in shallow waters from its preferred echinoderms to polychaetes, crustaceans and molluscs. Then the silver hake, a voracious and powerful swimmer, peaked in 1974, pursuing butterfish $P_{e p}$ rilus triacanthus and other small fishes that benefited by entering the sound when flounder numbers were low.

Trophic relations among this complex of migratory and resident groups are shown in Fig. 8. The whole was supported by a rich assortment of invertebrates, on which there can be selectivity of utilization at certain times and switching at others. Partial correlations for abundance have removed effects caused by the bay and sound winter flounder, showing particularly strong associations between squid co-occurring with small butterfish and scup; also strong was the silver hake-scup relation. These migrants associated negatively, however, with winter flounder, as shown by the power curves in Fig. 6.

In the grand pattern, flounder decreased during warmer winters; migrants were increasingly attracted to the sound, first by warmer summers then by food; and finally as flounder recovered during a return to cooler winters the surge of migrants went elsewhere. Seemingly minor increases in winter temperatures led to simple biotic responses that became complex as interactions developed between resident and migratory components. The total of all fishes, bay and sound, remained stable due to reciprocal changes taking place concurrently among component populations in this system of coupled habitats.

Acknowledgements. We are indebted to Dr. Candace A. Oviatt and Dr. William H. Krueger for making suggestions on early versions of the manuscript, Dr. Kenneth Sherman offered advice and encouragement on long-term data sets. Walter Berry and Skip Cynar assisted with sampling

\section{LITERATURE CITED}

Bigelow, H. B., Schroeder, W. C. (1953). Fishes of the Gulf of Maine. Fish. Bull. Fish Wildlf. Serv., Vol. 53, Bull. 74, p. 1-577

Dixon, W. J., Brown, M. B. (1977). BMDP Biomedical Computer programs P-series. Univ. Calif. Press, Berkeley

Jeffries, H. P., Johnson, W. C. (1974). Seasonal distributions of 
bottom fishes in the Narragansett Bay area: seven-year variations in the abundances of the winter flounder (Pseudopleuronectes americanus). J. Fish. Res. Bd Can. 31: $1057-1066$

Jeffries, H. P., Johnson, W. C. (1976). Petroleum, temperature and toxicants: examples of suspected responses by plankton and benthos on the continental shelf. In: Manowitz, B. (ed.) Effects of energy-related activities on the Atlantic continental shelf. Brookhaven National Laboratory, BNL 50484 , p. $96-108$

Laurence, G. C. (1975). Laboratory growth and metabolism of the winter flounder, Pseudopleuronectes americanus, from hatching through metamorphosis at three temperatures. Mar. Biol. 32: 223-229.
MacPhee, G. C. (1978). Synopsis of biological data for the winter flounder, Pseudopleuronectes americanus (Walbaum). NOAA Tech. Rpt. NMFS Circular 414, FAO Fish. Synopsis 117

MacArthur, R. H. (1972). Geographical ecology. Harper and Row, New York

Maurer, R. O., Bowman, R. E. (1975). Food habits of marine fishes of the Northwest Atlantic-data report. Northeast Fish. Ctr., Woods Hole, Massachusetts, Lab. Ref. 75-3, p. 1-90 (mimeo.)

U.S. Dept. of Commerce, National Oceanographic and Atmospheric Administration (NOAA). (1966-1982) Local climatological data, T. F. Green Airport, Providence, Rhode Island. Govt. Printing Office, Washington D. C.

This paper was presented by Professor S. W. Nixon; it was accepted for printing on June 24, 1985 